\title{
eBook: Temps líquids per a les biblioteques públiques
}

\section{MEI}

II, vol. 3

$n^{0} 4$
Emili Juan Soriano

Biblioteca Pública de l'Olleria
Recibido el 16-06-2011

Aceptado en 20-09-2011

\section{Resum}

Què fem amb els llibres electrònics?, és la pregunta que s'estan plantejant molts bibliotecaris mentre assisteixen perplexos a una competició frenètica sobre la distribució de continguts digitals i a la cursa accelerada de les empreses tecnològiques per presentar dispositius de lectura electrònica amb més prestacions.

La resposta no és senzilla, per això, les biblioteques públiques contemplen aquesta nova realitat amb un cert neguit, i alhora, com un nou repte per continuar sent una institució cultural central en la vida de les persones posicionant-se i adaptant els serveis i els continguts a les noves demandes dels usuaris, tenint present que, a dia de hui, el món digital i el món imprès no són excloents sinó complementaris.

El present article intenta analitzar aquesta nova realitat i planteja algunes de les accions a adoptar per part de les biblioteques públiques amb les incerteses pròpies dels "temps líquids" que travessa la nostra societat.

\section{Paraules clau}

Biblioteques públiques, Llibres electrònics, eBooks, Edició digital, Serveis bibliotecaris.

eBook : Time liquids for public libraries

Abstract

What about electronic books? This was the question being raised frequently many librarians while attending a competition frenzy perplexed about the distribution of digital content and an accelerated race technology companies to present new reading devices with more features.

The answer to this question is not easy to answer, and for this reason, the libraries provide for the new reality with a certain uneasiness, and at the same time, a challenge to remain a central cultural institution in the lives of people positioning and tailoring services and content to the new demands of users, given that, today, digital and print are not mutually exclusive but complementary.

This article attempts to analyze this new reality and poses some of the actions that should be adopted by public libraries with the uncertainty of the "liquid times" being experienced by our society.

\section{Keywords}

Public Libraries, electronic books, eBooks, digital edition, Library services.

"Ella está en el horizonte - dice Fernando Birri-. Me acerco dos pasos, ella se aleja dos pasos. Camino diez pasos y el horizonte se corre diez pasos más allá. Por mucho que yo camine, nunca la alcanzaré. ¿Para qué sirve la utopía? Para eso sirve: para caminar."

Eduardo Galeano. "Ventana sobre la utopía".

\section{Introducció}

El pensador Zygmunt Bauman va encunyar l'expressió temps líquids per referir-se al període d'incertesa que travessa la societat occidental en allò que fa referència al poder, la política, els espais de convivència i la nova responsabilitat de l'individu. La metàfora ens serveix com element

JUAN SORIANO, EMILI. “e-Book: Temps líquids per a les biblioteques públiques”. En: Métodos de información (MEI), II Época, Vol. 3, $\mathrm{n}^{0}, 4,2012$, pp. 73-85. 
introductori per emfasitzar que les biblioteques en general, i les públiques en particular, són presoneres, en part, d'eixes pors i poques certeses de què parla Bauman.

Certament, els impactes, ja siguen econòmics, culturals, informatius o polítics, que han provocat l'adveniment i consolidació d'aquest nou paradigma tecnològic sorgit amb l'anomenada societat de la informació, no passen de puntetes per la biblioteca, sinó que l'afecten de ple i des de diferents angles, obligant-la, si més no, a qüestionarse la pròpia "identitat".

Si fem una mirada retrospectiva als últims anys de la nostra vida ens adonem que hem integrat $i$, en molts casos, assimilat com a apèndixs del nostre cos, diferents estris tecnològics que ens acompanyen a tot arreu i ens apropen a uns volums d'informació que possiblement mai haguérem imaginat. Les xarxes electròniques, amb internet i la informació digital com a punta de llança, han modificat la concepció tradicional del temps i de l'espai, i han configurat, no per sí soles, una nova dimensió espacial i temporal que afecta a diferents aspectes de la vida quotidiana. Aquest fet constatable, reforça la tesi que la biblioteca haurà d'establir una nova relació amb l'usuari tenint en compte la capacitat que té aquest d'accedir autònomament a la informació sense filtres ni mediadors.

Entre aquestes eines tecnològiques que conjuguen sovint connectivitat i mobilitat, darrerament s'han popularitzat els suports dedicats a la lectura. Sobre dispositius tecnològics en parlarem tangencialment al present article, en centrarem sobretot en els continguts. Sense ser excessivament pretensiosos, volem abordar la transformació cultural que representa la introducció del llibre electrònic en les biblioteques públiques i com incideix en relació als usuaris, les col·leccions o els espais.

Certament, els resultats que s'hi mostren són poc concloents ja que, en un context de gran efervescència tecnològica, resulta complicat constatar i predir amb exactitud quin serà l'impacte real que tindrà sobre els centres de lectura, encara que hi ha senyals que permeten conjecturar que el suport digital librari guanyarà adeptes de manera exponencial a curt termini. Dos exemples, que no per puntuals i anecdòtics, mostren clarament aquesta tendència, seria l'arribada a l'Estat espanyol de la gran botiga virtual que és Amazon o el canvi de disseny de la prestatgeria Billy de la multinacional sueca Ikea davant la possible desaparició del llibre físic.

Les biblioteques públiques s'hauran d'enfrontar, doncs, a la nova situació que es planteja, com a mínim, des d'una doble vessant. En primer lloc, adaptant els seus serveis, espais i processos al nou escenari que s'intueix, i en segon lloc, garantint la coexistència harmònica entre el llibre tradicional i l'electrònic per garantir la igualtat d'accés a la informació com un dels principis bàsics de la biblioteca pública.

Sobre aquests dos eixos s'estructura el treball "E-book. Temps líquids per a les biblioteques públiques", l'objectiu bàsic del qual serà determinar quines són les passes que han de donar les biblioteques públiques per reinventar-se novament i adaptar-se a una nova realitat que irromp desbocada, amb molts dubtes i poques conviccions. 
Assolir aquest objectiu no resultarà senzill. Seria fàcil llançar proclames profètiques sobre la desaparició del llibre en paper i la substitució pel llibre electrònic i, fins i tot, afirmar la desaparició de les biblioteques. Tot i això, la realitat és molt més complexa i no tenim indicis que les visions apocalíptiques sobre el futur del llibre imprés i de les biblioteques s'hagin de concretar. Més aviat, ens animen a reforçar una anàlisi acurada sobre les noves formes de lectura i la modificació d'hàbits culturals i de consum, la millora permanent dels dispositius, la legislació o la nova relació que estableixen els usuaris amb la biblioteca.

L'estudi s'ha nodrit d'una bibliografia prolífica en els darrers temps sobre la qüestió motiu d'anàlisi, però esbiaixada, en el sentit que la producció científica publicada para molta atenció a les biblioteques acadèmiques i passa de puntetes sobre l'impacte que està tenint el llibre electrònic en les biblioteques públiques malgrat que sembla corregir-se de mica en mica aquest dèficit.

\section{Metodologia i recursos}

Sovint la terminologia presenta una polisèmia que pot provocar una certa confusió. En el cas del llibre electrònic o e-book, en ocasions s'empra tant per anomenar el dispositiu (e-reader) com el contingut digital. En el nostre cas, tot i que tangencialment podem parlar dels dispositius de lectura (e-reader), el nostre objecte d'estudi és el llibre: el contingut.

Feta aquesta precisió, el present treball pretén descriure a trets generals com s'està abordant la introducció del llibre electrònic en les biblioteques públiques. Per fer-ho, hem emprat articles i ponències científiques, estudis institucionals d'administracions públiques i associacions professionals, així com visions particulars o empresarials expressades a través de blocs o websites.

La tasca investigadora s'ha sustentat principalment en la lectura d'articles científics produïts els dos darrers anys, donat que en un context tecnològic en contínua agitació resulta imprescindible estar alerta davant els canvis, tot i que, també ens ha resultat enriquidor poder comparar reflexions anteriors de quan el mercat del llibre electrònic era incipient i els pronòstics eren més arriscats. En tot cas, hem percebut, tret d'alguna excepció concreta, una certa mancança d'articles o estudis que analitzaren l'impacte real amb experiències concretes de biblioteques públiques. Aquesta escassetat de publicacions s'accentua en el cas de les biblioteques públiques valencianes.

Sens dubte, una de les grans mancances del present treball és la inexistència d'un treball de camp propi que podés aproximar-nos a la realitat més immediata de les biblioteques del nostre entorn. Dit això, hores d'ara, com ja hem comentat anteriorment, es troben a faltar treballs empírics que mostren quin està sent l'impacte real que està tenint la incipient introducció de l'e-book, almenys en les biblioteques públiques de l'àmbit valencià i espanyol. Tot i això, hi ha iniciatives lloables com el Programa e-Book y Biblioteca que du a terme la Fundación Germán Sánchez Ruipérez i que estan servint per investigar, experimentar i innovar en tres escenaris: 
bibliotecaris, usuaris i espais de lectura en relació amb el llibre electrònic.

\section{Experiències i resultats}

Les tecnologies de la informació i la comunicació han transformat, no per sí soles, evidentment, els hàbits de lectura i consum de les persones. Aquest fet repercuteix directament sobre les relacions que estableixen els usuaris amb la biblioteca i en la manera que aquesta ha d'oferir les seues alternatives.

En aquest sentit, la fusió de mitjans digitals (smartphones, tablets, ordinadors portàtils, e-readers, etc.) permeten la comunicació i l'accés a la informació amb independència de si s'apropen o no a l'espai físic bibliotecari, ampliant per tant, la capacitat de gestió dels propis usuaris. Aquesta nova realitat obri noves formes de participació i acció dels usuaris però també obliga la biblioteca a diversificar i customitzar els seus continguts, no només per a aquest col-lectiu sinó també per a aquells que continuen utilitzant els serveis de la biblioteca a la manera tradicional (préstec físic de llibres, lectura en sala, etc.).

Tanmateix, es constata que si bé l'adquisició de lectors i la publicació de llibres en format electrònic per part de les empreses editorials va creixent de manera significativa, trobem que per part de les biblioteques públiques el procés d'incorporació d'aquest format a les col·leccions va molt a poc a poc, si més no en comparació amb les biblioteques universitàries, les quals han assumit el suport digital, especialment, en la subscripció a revistes electròniques com a suport de la docència i la investigació.

De fet, les experiències referenciables s'han centrat més en el préstec de dispositius amb obres de domini públic lliures de drets d'autor que no pas en la implementació de plataformes que permeten el préstec de llibres incorporant el sistema DRM (Digital Rights Management) que fan desaparèixer el llibre del dispositiu una vegada s'ha exhaurit el termini de préstec.

Així, l'experiència que es va promoure des del Ministerio de Cultura de dotar a les biblioteques públiques de l'Estat de lectors de llibres electrònics s'insereix en aquesta línia. Les biblioteques públiques de Catalunya i Madrid estan anant una mica més enllà, han engegat, després d'analitzar i avaluar el servei de préstec d'e-readers, una prova pilot (Domínguez; Guerrero; Jáudenes; Renedo; Vives, 2011) per crear una plataforma que permeta el préstec de llibres electrònics en línia suportada pel programa Odilotk de l'empresa Biblio3000. La plataforma s'integra al catàleg i l'usuari només necessita estar autenticat per poder descarregar el llibre que es prestat durant un temps determinat i s'elimina transcorregut eixe període, a més, garantitza i respecta el compliment de la legislació sobre drets d'autor i facilita la interacció amb els usuaris que poden valorar i efectuar comentaris sobre les obres prestades.

A Galícia, la Rede de Bibliotecas de Galicia ha posat en marxa un servei de préstec en línia de llibres electrònics per part de les biblioteques públiques dins el projecte Galicia eBooks. Aquesta iniciativa naix amb certes limitacions, especialment per la 
insuficient col-lecció de títols i perquè cal que els dispositius de lectura siguen cedits per les pròpies biblioteques, per contra, té l'avantatge que permet enriquir continguts mitjançant aplicacions de la web social. La plataforma que permet la gestió del préstec online de les col-leccions digitals és XeBook desenvolupat per l'empresa Xercode.

Les informacions de què disposem ens permeten afirmar que des de l'administració autonòmica valenciana s'està alerta davant la incorporació a curt termini de noves col-leccions digitals o sobre la possibilitat de posar en marxa una plataforma integrada dins el catàleg de la Xarxa de Lectura Pública Valenciana que permeta el préstec dels llibres electrònics però amb cautela. La qüestió legal sobre la possible infracció dels drets de propietat intel·lectual són un fre que reforcen la prudència i, la situació econòmica que travessa l'administració autonòmica valenciana, la refermen.

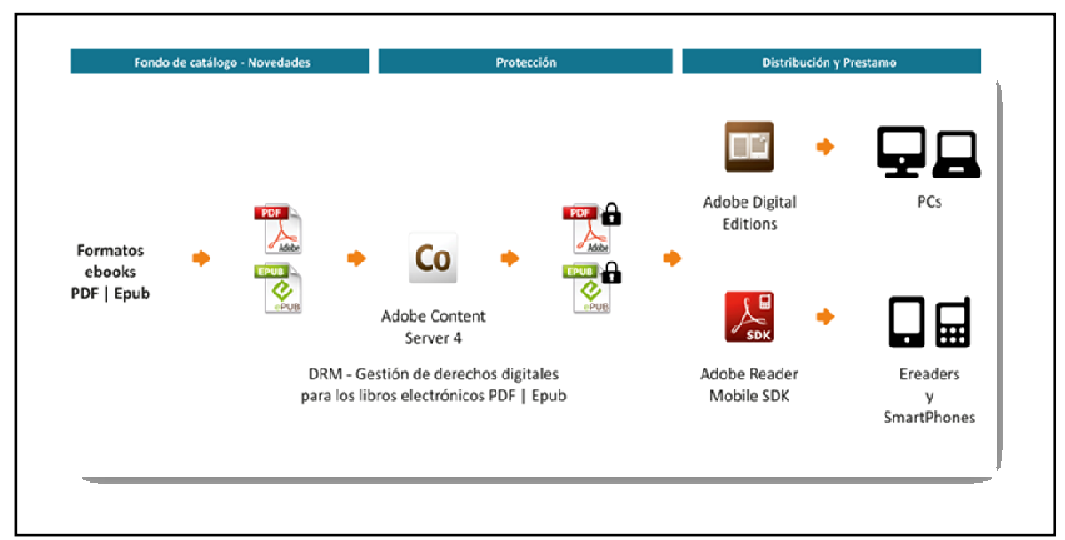

Figura 1. Gestió de drets digitals per als llibres electrònics PDF Epub. Font: Xercode

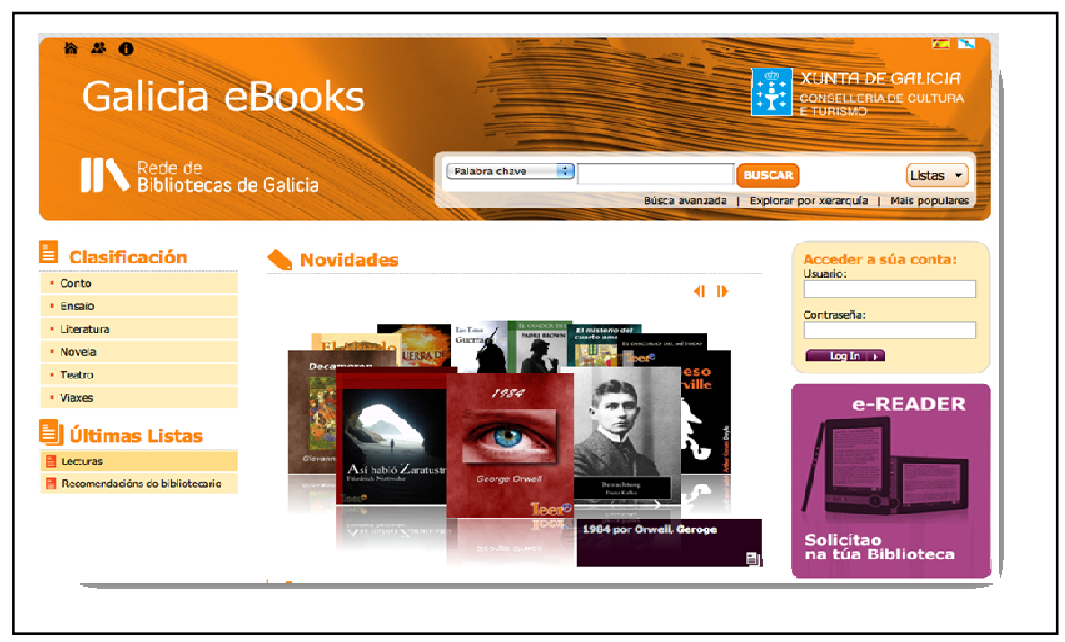

Figura 2. Galicia eBooks

En altres països de l'entorn europeu i als EEUU, la situació és diferent ja que des de fa cert temps s'han implementat mecanismes d'accés als llibres electrònics per part dels usuaris i s'ha augmentat significativament l'oferta de les col-leccions digitals. De fet, segons un estudi recent de l'American Library Association actualment, de 
mitjana, el $67 \%$ de les biblioteques públiques nordamericanes ofereixen servei de préstec gratuït de llibres electrònics (ALA, 2011).

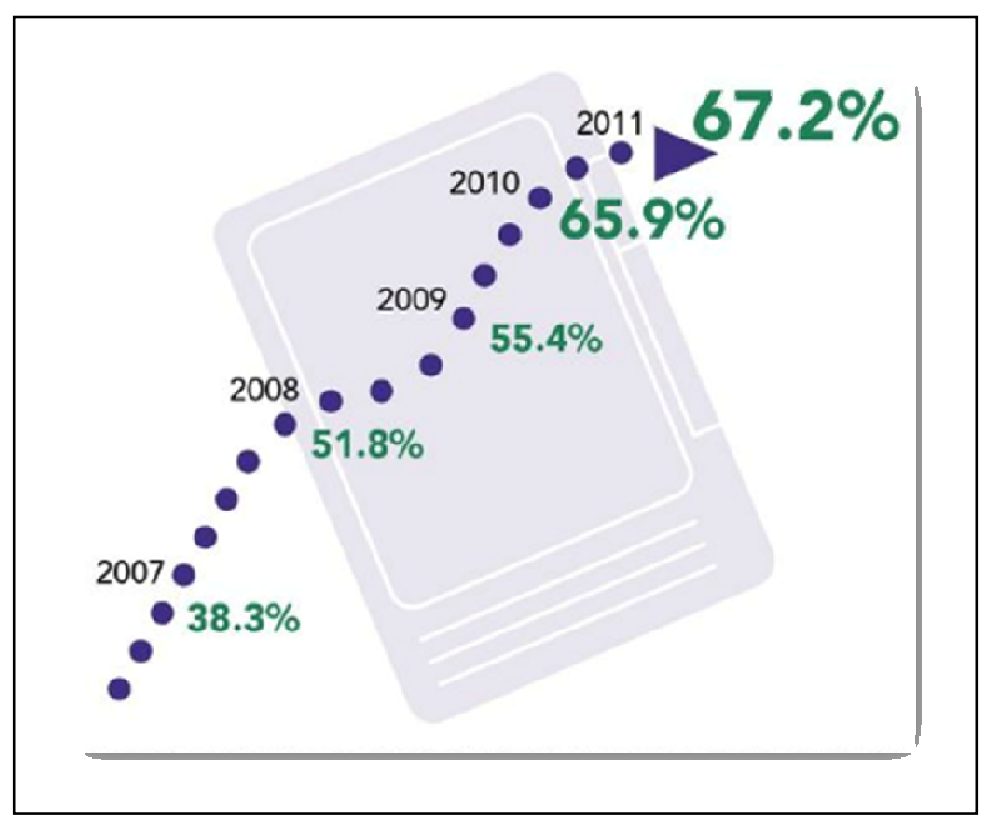

Figura 3 Disponibilitat de llibres electròniques a les biblioteques públiques nord-americanes. Font: ALA

Moltes d'aquestes biblioteques utilitzen Overdrive. Una plataforma que és compatible amb els sistemes de gestió de les biblioteques i s'integra en el web i el catàleg de la biblioteca permetent un préstec simultani per usuari, és a dir, reprodueix el tradicional servei de préstec que ha caracteritzat les biblioteques públiques però prestant llibres electrònics.

Té com a principal inconvenient que no és comercialment neutre, és a dir, subministra la tecnologia i els continguts, sent Overdrive qui arriba a acords comercials amb les empreses editorials. Per exemple, la New York Public Library o South Dublin Libraries utilitzen aquesta plataforma. 


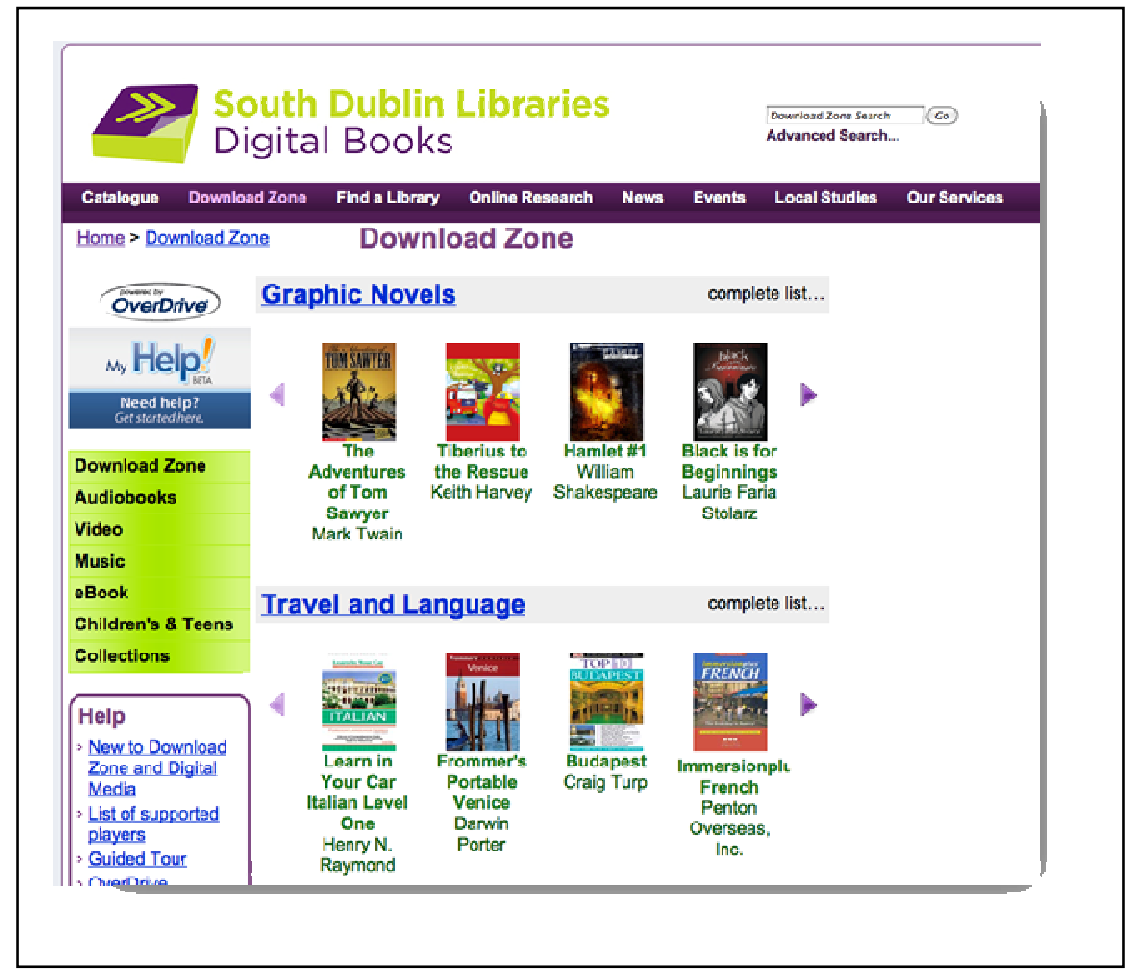

Figura 4 Captura de pantalla de la New York PublicLibrary

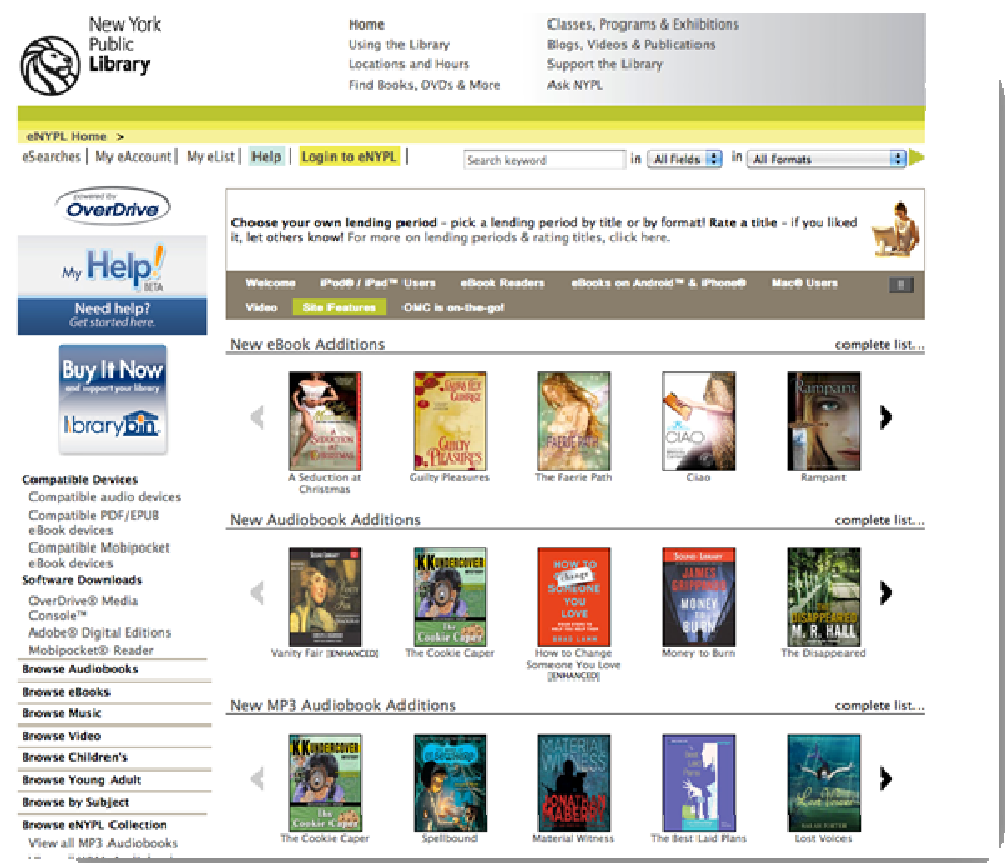

Figura 5 Captura pantalla South Dublin Libraries 
Sens dubte, disposar d'una plataforma tecnològica que permeta reproduir online el que tota la vida la biblioteca pública ha realitzat de forma presencial i garantir el compliment de la legalitat vigent respecte dels drets d'autor són aspectes importantíssims que la biblioteca pública ha de tenir en compte alhora de plantejar-se abordar un projecte d'aquestes dimensions. Tanmateix, hi ha altres aspectes que no deuen menysprear-se perquè poden repercutir negativament en els resultats que s'assolisquen.

Així, caldrà tindre en compte la diversitat de formats i el preu, tant dels dispositius com dels llibres. Aquest fet, representa un fre que augmenta la cautela de les biblioteques, ja que, en el cas dels formats, malgrat que darrerament s'està imposant l'e-pub, existeix una ampla varietat que no sempre pot ser llegida per tots els models d'e-readers. Una mostra significativa d'aquesta diversitat la podem apreciar en el gràfic extret de la $2^{\text {a }}$ Encuesta sobre el libro digital elaborada pel Gremio de Editores de España.

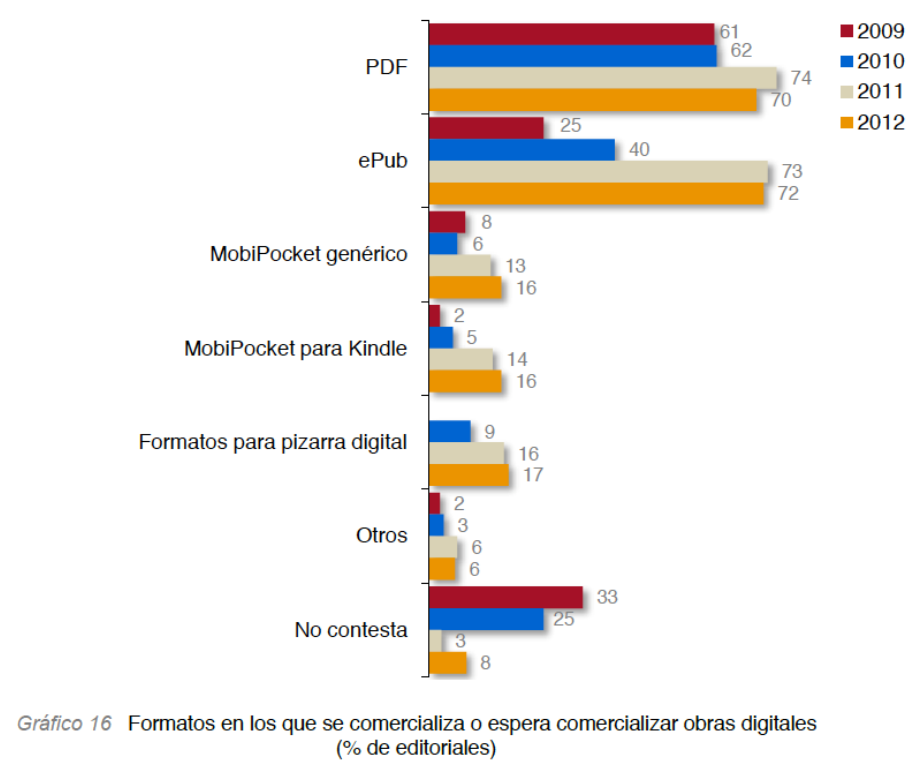

Figura 6. Gràfic de la $2^{\text {a }}$ encuesta sobre el libro digital en España. Federación del Gremio de Editores de España

Un altra qüestió gens frívola, sinó més bé, transcendental, és què pensen i com actuen els usuaris davant el nou escenari que se’ns presenta. L'èxit o el fracàs de la iniciativa estarà estretament lligat a la receptivitat dels usuaris i al fet que desenvolupen un paper actiu. Sembla ser, arran dels diferents estudis que s'han dut a terme que, en línies generals, la valoració dels usuaris és positiva i mostren un cert convenciment que el futur del llibre serà digital i que caldrà adaptar-se progressivament, tot i que, molts d'ells troben a faltar l'efecte sensorial que els produeix el llibre en paper (Fernández; Millán, 2011).

Fruit de l'observació i el seguiment de les experiències ressenyades, apreciem que les biblioteques públiques davant la possibilitat que els llibres electrònics passen a 
formar part de les seues col-leccions i puguen ser posats a disposició dels seus usuaris semblen estar alerta, temptejant i expectants davant les transformacions que la cadena de valor del llibre i el model de negoci estan experimentant, i també, seduïts i temerosos alhora, perquè si bé per a alguns representa una amenaça, per a d'altres, representa l'oportunitat de continuar reformulant el rol que les biblioteques públiques han de desenvolupar en la societat de la informació i el coneixement.

El llibre electrònic obri una ampli ventall de possibilitats per a les biblioteques públiques, les quals, sense deixar de banda el model de negoci tradicional, han d'incorporar aquests continguts. Al llibre Gutenberg 2.0 (Cordón; Gómez; Alonso, 2011) s'enumeren algunes de les expectatives bibliotecàries davant la irrupció i progressiva consolidació de l'e-book.

\begin{tabular}{l}
\hline \multicolumn{1}{c}{ EXPECTATIVES BIBLIOTEQUES } \\
\hline Actualització de continguts \\
Rapidesa i immediatesa en la publicació \\
Fàcil accés \\
Rendabilitat cost-benefici \\
Efectivitat i integració de les plataformes en les col·leccions \\
Accés permanent front a les llicències d'ús \\
Accés multiusuari \\
Integració en l'OPAC \\
Formats normalitzats
\end{tabular}

Tabla 1. Expectatives de les biblioteques

S'albira, doncs, un escenari de canvi, i queda palesa, la necessitat de trobar camins que permeten explotar els avantatges que presenta el format electrònic en quant a l'accés als continguts o l'estalvi en espai, i d'altra banda, la minimització dels efectes negatius que podria comportar. Sens dubte, hauran de confluir els interessos comercials de les empreses editores, amb els de la biblioteca com a intermediari cultural i els de l'usuari com a destinatari final del producte.

\section{Conclusions}

Les dades de què disposem, preferentment provinents dels estudis publicats per analistes i institucions, ens permeten dibuixar amb brotxa grossa quina és la realitat actual en la introducció dels llibres electrònics en les biblioteques públiques valencianes i espanyoles $i$, en quina mesura s'estan transformant els serveis bibliotecaris i la relació de la biblioteca amb els usuaris.

La decisió d’introduir el llibre electrònic en les biblioteques públiques, en tot cas, no s'haurà de prendre a la babalà sinó que requereix d'unes fases d'estudi, planificació, avaluació i difusió que han de garantir l'èxit de l'empresa. Per aquest motiu, realitzar 
exercicis de benchmarking i comparar què fan altres biblioteques públiques en altres contrades o identificar les expectatives dels usuaris és de vital importància per assolir l'objectiu fonamental d'oferir des de la biblioteca pública un nou servei amb aquests documents.

Convindria, en tot cas, clarificar que el fet que aquesta mena d'iniciatives es troben en els estadis inicials obri un ventall de possibilitats que el temps dictarà si s'han sabut aprofitar o no per part de les biblioteques públiques, malgrat que les expectatives des del punt de vista tecnològic siguen assumibles. Una altra cosa és que ho siguen des del punt de vista organitzatiu, atés que les biblioteques públiques depenen jurídicament d'administracions públiques, especialment de l'administració local, les quals, hores d'ara, travessen una conjuntura econòmica gravíssima que dificulta l'assumpció de projectes d'aquesta mena.

La solució possiblement passa per la cooperació bibliotecària, creant xarxes i aprofitant les que ja operen, per poder compartir recursos i fer més sostenibles aquestes inversions. Hores d'ara, per l'ofegament financer de l'administració local com a principal sostenidor de les biblioteques públiques, difícilment una biblioteca pot posar en marxa pel seu propi compte un ambiciós projecte que integre el llibre electrònic en tots els processos i serveis que presta, i per això, es requereix d'una major implicació i visió estratègica per part de les administracions supralocals. Certament, la popularització del llibre electrònic comporta múltiples transformacions en gairebé tots els aspectes de la indústria editorial i els hàbits de consum i lectura, i això repercuteix directament sobre les biblioteques, i especialment, sobre les biblioteques públiques. Per això, i perquè el canvi és gradual i progressiu i encara es troba en les seues fases inicials, resulta dificultós aventurar-se a explicitar conclusions atés que hi manquen elements de judici suficients per ser categòrics. Ara bé, les diferents lectures que hem anat fent $\mathrm{i}$ la pròpia experiència professional ens permeten aproximar-nos i discernir amb cautela però sense por d'errar, algunes evidències.

- L'impacte del llibre electrònic, a dia de hui, és moderat en les biblioteques públiques espanyoles, en tant en quant necessita d'un període de coexistència amb el llibre tradicional, si més no, el lapse de temps suficient per reduir els efectes negatius que pot representar l'escletxa digital per a determinats col-lectius d'usuaris. El món digital i l'imprés no són excloents, són complementaris i la substitució d'un per l'altre (si es produeix) serà progressivament i gradual, però "avançant cap a la cohabitació, de presència i i importància compartides per igual: una biblioteca digital de fàcil accés, ubiqua, oberta permanentment; i una biblioteca física que esdevindrà l'edifici social per excel·lència, un lloc de trobada ciutadà.” (Fernández Galiano, 2011)

- El llibre electrònic és poc madur des d'una doble vessant. Des del punt de vista tecnològic existeix nombrosos formats que dificulten l'estandardització, i conseqüentment, una aposta decidida de les biblioteques; d'altra banda, en allò que fa referència a les col-leccions, no s'ha assolit encara l'amplitud i diversificació del llibre imprés, si bé, s'està ampliant exponencialment l'oferta de les editorials, llibreries i distribuïdores. Alguns autors parlen també que el 
nivell d'obsolescència (Franganillo, 2010) del llibre electrònic és superior al del paper.

- La generalització del suport digital i l'accés massiu dels usuaris a amplis volums d'informació, intervenint els receptors en l'articulació dels processos comunicatius, està transformant substancialment la relació de la biblioteca amb els seus usuaris desestabilitzant la funció tradicional del professional de la informació com a mediador. Ara bé, aquesta mediació no ha de desaparèixer, sinó que s'ha de redefinir en l'entorn digital, adquirint noves habilitats i, segurament, prescindint de tasques que li han estat pròpies durant molt de temps.

- La reformulació dels rols professionals duu implícita el desenvolupament de noves competències, entre d'altres, en els processos de selecció i gestió de continguts, tenint en compte les necessitats dels usuaris, una anàlisi acurada dels continguts, els models de negoci i els drets d'accés.

- Les indefinicions actuals del mercat editorial en allò que fa referència a la gestió dels drets d'autor de les obres en la seua versió electrònica alenteix els processos d'introducció mentres no es trobe una fórmula legal que satisfaça a totes les parts. En tot cas, s'haurà de procurar per la complementarietat i coexistència amb els documents lliures de drets. Les experiències en altres països europeus poden ser un bon punt de partida.

- La generalització del llibre electrònic en les biblioteques públiques transformarà l'espai i alguns dels seus serveis més exitosos com és el préstec. La biblioteca, l'espai més icònic i emblemàtic de la informació, esdevindrà un lloc de trobada ciutadà però potser lluny de la concepció que fins ara hem tingut d'aquest espai. El model de biblioteca nòrdic potser una fita en l'horitzó.

Certament, la biblioteca, una institució capdavantera en la introducció d'internet, viu moments apassionants dels quals ha de sortir reforçada. Tanmateix, no ho aconseguirà sinó és capaç de realitzar un profund exercici de revisió de la seua funció social en la societat actual, repensant i redefinint el seu model per continuar facilitant una accés ampli i sense cap mena de marginació ni exclusió a les fonts d'informació i la cultura.

La incorporació del llibre electrònic serà un dels elements claus que obligaran a eixe reequilibri. Tindrà afectacions sobre diferents aspectes de la gestió i el disseny dels serveis bibliotecaris (ampliació de col·leccions, etc), processos tècnics, i també en la relació amb els usuaris i amb el propi mercat editorial, però hi ha una evidència incontestable, el llibre electrònic ha arribat i ho ha fet per quedar-s'hi. En la mesura que les biblioteques públiques siguen capaces d'adaptar-se a aquesta nova realitat en sortiran reforçades i continuaran sent la institució que garantitze que els ciutadans i les ciutadanes disposen d'igualtat d'oportunitat en l'accés i l'ús de les fonts de coneixement i cultura, sinó és així, en sortiran malmeses en el seu prestigi i els depararà un futur incert i submergit en períodes "líquids". 


\section{Bibliografia}

Alonso Arévalo, J., Cordón García, J. A. (2010a). El libro electrónico en el ecosistema de la información. Ciencias de la Información. Instituto de Información Científica y Tecnológica (IDCTC), 41(2), 58-68 Disponible en: <http://eprints.rclis.org/bitstream/10760/14891/1/Libro_electronico_\% 28Ciencais_de_la_Informaci\%c3\%b3n\%29.pdf $>$ [Consulta: 19/09/2011]

Alonso Arévalo, J., Cordón García, J. A. (2010b). El libro electrónico ha llegado a las bibliotecas... y viene para quedarse. Mi Biblioteca. Fundación Alonso Quijano para el fomento de la lectura, 23, 74-83 Disponible en: <http://eprints.rclis.org/bitstream/10760/15373/1/Quedarse.pdf> [Consulta: $19 / 09 / 2011]$

Alonso Arévalo, J., Cordón García, J. A. (2010c). Las políticas de adquisición de libros electrónicos en bibliotecas: licencias, usos y derechos de autor. En: V Congreso Nacional de Bibliotecas Públicas 3-5 de noviembre 2010, Gijón. Disponible en: <www.mcu.es/bibliotecas/MC/2010/CongresoBP/ Comunicaciones.html> [Consulta: 19/09/2011]

Alonso Arévalo, J., Cordón García, J. A., Martín Rodero, H. (2010d). Los libros electrónicos: la tercera ola de la revolución digital. Anales de Documentacion, 13, 53-80. Disponible en: <http:// revistas.um.es/analesdoc/article/download/106991/101681> [Consulta: 19/09/2011]

Alonso Arévalo, J. Cordón García, J. A., Gómez Díaz, R., (2011). Gutenberg 2.o: La revolución de los libros electrónicos. Gijón: Trea.

American Library Association (2011). Public library funding \& technology access study $2010-2011$. En: American Library Magazine, Summer 2011102 p. Disponible en: <http://viewer.zmags.com/ publication/857ea9fd - /857ea9fd/1> [Consulta: 19/09/2011]

Anglada, L. (2008). A propósito de libros electrónicos. El Profesional De La Información, 17(4), 414415. Disponible en: <www.elprofesionaldelainformacion.com/contenidos/2008/julio/o7.pdf > [Consulta: 19/09/2011]

Celaya, J. (2008). La empresa en la web 2.0. Barcelona: Gestión 2000.

Celaya, J. , Iriarte, J. (201 1, Setembre 19). Los “cacharros” transforman los hábitos culturales. [Weblog post]. Disponible en: <www.dosdoce.com/articulo/opinion/3685/los-cacharrostransforman-los-habitos-culturales / $>$ [Consulta: 19/09/2011]

Clavero, J., Codina, M., Perez, A., Serrat-Brustenga, M. (2009). A case study of lending service of electronic books. Profesional De La Informacion, 18(2), 237-241.Disponible en: < http:// upcommons.upc.edu/e-prints/bitstream/2117/2846/1/clavero_estudiocaso.pdf > [Consulta: $19 / 09 / 2011]$

Corrionero, F. (2010). Creando e-bibliotecarios: un viaje de película a Territorio Ebook. En: V Congreso Nacional de Bibliotecas Públicas 3-5 de noviembre 2010, Gijón. Disponible en: <www.mcu.es/bibliotecas/MC/2010/CongresoBP/Comunicaciones.html> [Consulta: 19/09/2011]

Danish Agency for Libraries and Media (2010) Nordic Public Libraries 2.0. Copenhaguen. Disponible en: <www.bibliotekogmedier.dk/fileadmin/publikationer/publikationer_engelske/Nordic_public/ Nordic_Public_Libraries_2.0.pdf $>$ [Consulta: 19/09/2011]

Davies, D. M. (2010). E-books. Public Libraries, 49(4), 10-53.

Domínguez, P., Guerrero, Y., Jáudenes, M., Renedo, C., Vives, J. (2011) Desenvolupament del servei de préstec en línia de llibres electrònics en les biblioteques públiques de Catalunya i de la Comunitat de Madrid. BiD: textos universitaris de biblioteconomia i documentació, 26. Disponible en: <www.ub.edu/bid/26/vives 1.htm > [Consulta: 19/09/2011] 
Drinkwater, K. (2010). E-book readers: What are librarians to make of them? SCONUL Focus, no.49, Pp.4-9, Disponible en: <www.sconul.ac.uk/publications/newsletter/49/2.pdf> [Consulta: $19 / 09 / 2011]$

Duncan, R. (2010). Ebooks and beyond: The challenge for public libraries. APLIS, 23(2), 44-55.

Federación de Gremio de Editores de España (2011) 2 $2^{a}$ encuesta sobre el libro digital en España: impacto de la digitalización en el catálogo, canales de distribución y de venta y política comercial. Madrid. Disponible en: <www.mcu.es/libro/docs/MC/Observatorio/pdf/ encuesta_libro_digital_2011.pdf> [Consulta: 19/09/2011]

Fernández, P., Millán, J. A. (2011?). Experiencia con préstamos de e-books en bibliotecas de Obra Social Caja Madrid: avance de resultados. Disponible en: <www.slideshare.net/jamillan/presentacincasa-encendida-versin-4 > [Consulta: 19/09/2011]

Fernández-Galiano, L. (2010) La biblioteca digital. Arquitectura Viva. 135, p. 3.

Franganillo, J. (2009). Ni libros vencedores ni libros vencidos. Anuario ThinkEPI 2009. 30-33. Disponible en: <http://franganillo.es/franganillo2009e.pdf > [Consulta: 19/09/2011]

Generalitat de Catalunya. Departament de Cultura i Mitjans de Comunicació (2009). Imagina la biblioteca pública del S. XXI. Extracció de dades de les enquestes. Barcelona. Disponible en: $<$ www.imaginalabiblioteca.cat/> [Consulta: 19/09/2011]

Gil-Solés, D. (2011, Maig 13). Les tres revolucions vers la biblioteca digital. [Weblog post]. Disponible en: <www.bauenblog.info/2011/05/13/les-tres-revolucions-vers-la-biblioteca-digital/> [Consulta: 19/09/2011]

Ministerio de Cultura (2009). El libro y las nuevas tecnologías. El libro electrónico. Madrid. Disponible en: <www.mcu.es/libro/docs/MC/CD/LIBROELECTRONICO.pdf> [Consulta: $19 / 09 / 2011]$

OCLC. (2010) Perceptions of libraries 2010. Context and Community. A report to the OCLC Membership. By Cathy de Rosa et al. Disponible en: <www.oclc.org/us/en/ reports/2010perceptions.htm> [Consulta: 19/09/2011]

Porter, M., \& King, D. L. (2010). E-books, E-book readers, and next steps. Public Libraries, 49(6), 2023.

Vicente-De-Billion, C., Oyarce-Gatica, A. (2010). ¿Está muriendo la biblioteca? Hacia la E-evolution. El Profesional de la Información, 19(1), 70-76. Disponible en: <http://eprints.rclis.org/ bitstream/10760/14382/1/Est\%C3\%A1_muriendo_la_biblioteca_Hacia_la_e-evoluci\%C3\%B3n.pdf > [Consulta: 19/09/2011]

Zimerman, M. (2011). E-books and piracy: Implications/Issues for academic libraries. New Library World, 112(1-2), 67-75. 